\title{
KEPASTIAN HUKUM TERHADAP ANAK HASIL DARI PERKAWINAN CAMPURAN MENURUT UNDANG-UNDANG NOMOR 12 TAHUN 2006 TENTANG KEWARGANEGARAAN REPUBLIK INDONESIA
}

\author{
Joejoen Tjahjani \\ Dosen Fakultas Hukum Universitas Islam Lamongan
}

\begin{abstract}
ABSTRAK
Perkawinan campuran merupakan perkawinan antara dua orang yang di indonesia tunduk pada hukum yang berlainan, karena perbedaan kewarganegaraan dan salah satu pihak berkewarganegaraan asing dan salah satu pihak berkewarganegaraan indonesia. Tipe penelitian hukum yang dilakukan adalah yuridis normatif (hukum normatif). Metode penelitian hukum normatif adalah suatu prosedur penelitian ilmiah untuk menemukan kebenaran berdasarkan logika keilmuan hukum dari sisi normatifnya. Sedangkan bahan hukum sekunder adalah bahan yang diperoleh dari buku teks, jurnal-jurnal, pendapat para sarjana dan kasus-kasus hukum. Pemberlakuan Undang-Undang Nomor 12 Tahun 2006 Tentang Kewarganegaraan Republik

Indonesia, terkait dengan mobilitas dan aktivitas "antar manusia antar negara". Dan merupakan solusi yang dianggap terbaik untuk memecahkan permasalahan yang rentan dan sensitif yaitu kewarganegaraan seseorang terkait dengan status kedudukan hukum anak hasil perkawinan campuran antara Warga Negara Indonesia dengan Warga Negara Asing. Anak hasil perkawinan campuran hendaknya memanfaatkan ketentuan tersebut untuk melegalisasikan kewarganegaraan sesudah 18 tahun.
\end{abstract}

Kata Kunci : Kepastian hukum, Perkawinan Campuran, Undang - undang no.12 Th.2006

\section{PENDAHULUAN}

Perkawinan di Indonesia diatur dalam Undang-Undang Nomor 1 Tahun 1974 tentang Perkawinan. Pengertian Perkawinan menurut Pasal 1 ialah : "Ikatan lahir batin antara seorang pria dengan seorang wanita sebagai suami istri dengan tujuan membentuk keluarga (rumah tangga) yang bahagia dan kekal berdasarkan Ketuhanan Yang Maha Esa”. Perkawinan, merupakan pertalian yang sah antara seorang lelaki dan seorang perempuan untuk waktu yang lama. Undang-undang memandang perkawinan hanya dari hubungan keperdataan, demikian Pasal 26 Burgerlijk Wetboek. ${ }^{1}$ Perkawinan merupakan suatu peristiwa penting dalam kehidupan manusia, karena

1 Subekti, Pokok-Pokok Hukum Perdata, (cetakan ke-31), Jakarta : Intermasa, 2003, h. 23. 
perkawinan tidak saja menyangkut pribadi kedua calon suami istri, tetapi juga menyangkut urusan keluarga dan masyarakat. Pada umumnya perkawinan dianggap sebagai sesuatu yang suci dan karenanya setiap agama selalu menghubungkan kaedah perkawinan dengan kedah-kaedah agama.

Manusia dalam menempuh pergaulan hidp dalam masyarakat, ternyata tidak dapat terlepas dari adanya saling ketergantungan antara manusia dengan yang lainnya. Hal itu dikarenakan, sesuai dengan kedudukan manusia sebagai mahluk sosial, yang suka berkelompok atau berteman dengan manusia lainnya. Hidup bersama merupakan salah satu sarana untuk memenuhi kebutuhan hidup manusia, baik kebutuhan yang bersifat jasmani maupun yang bersifat rohani. Demikian pula bagi seorang laki-laki ataupun seorang perempuan yang telah mencapai usia tertentu, maka ia tidak akan lepas dari permasalahan tersebut. Ia ingin memenuhi kebutuhan hidupnya, dengan melaluinya bersama dengan orang lain yang bisa dijadikan curahan hati penyejuk jiwa, tempat berbagi suka dan duka. Hidup bersama antara seorang laki-laki dan perempuan sebagai pasangan suami istri dan telah memenuhi ketentuan hukumnya, ini yang lazimnya disebut sebagai sebuah perkawinan.

Perkawinan (pernikahan) pada hakekatnya, adalah merupakan ikatan lahir dan batin antara seorang laki-laki dan perempuan untuk membentuk suatu keluarga yang kekal dan bahagia. Perkawinan campuran telah, merambah seluruh pelosok Tanah Air dan kelas masyarakat. Globalisasi informasi, ekonomi, pendidikan, dan transportasi telah menggugurkan stigma bahwa kawin campur adalah perkawinan antara ekspatriat kaya dan orang
Indonesia. ${ }^{2}$ Menurut survei yang dilakukan oleh Mixed Couple Club, jalur perkenalan yang membawa pasangan berbeda Kewarganegaraan menikah antara lain adalah perkenalan melalui internet, kemudian bekas teman kerja/bisnis, berkenalan saat berlibur, bekas teman sekolah/kuliah, dan sahabat pena. Perkawinan campuran juga terjadi pada tenaga kerja Indonesia, dengan tenaga kerja dari negara lain. ${ }^{3}$ Dengan banyak terjadinya perkawinan campuran di Indonesia, sudah seharusnya perlindungan hukum dalam perkawinan campuran ini diakomodir dengan baik dalam perundangundangan di Indonesia.

Berbagai masalah yang dihadapi Negara Indonesia ternyata membawa imbas kepada perubahan dalam berbagai hal. Diantaranya adalah adanya perubahan Undang-Undang Nomor 62 Tahun 1958 menjadi Undang-Undang Nomor 12 Tahun 2006 Tentang Kewarganegaraan Republik Indonesia. Perubahan tersebut juga mendasari adanya perubahan aturan dalam Keimigrasian Indonesia. Fenomena ini merupakan fenomena yang harus disikapi bersama oleh banyak kalangan. Perubahan ini tentu akan membawa dampak positif atau negatif terhadap setiap Warga Negara Indonesia yang melakukan perkawinan dengan Warga Negara Asing. Kedua sisi ini tentu selalu berdampingan. Untuk menghindari hal itu, agar semua komponen aktif mengamati bahkan menilai perubahan yang terjadi. Karena bagaimanapun baiknya, Undang-Undang kalau memang belum diketahui dan dipahami seluruh warga negara, maka akan membawa dampak tersendiri, terutama pada hubungan antara Indonesia umumnya dengan Negara lain.

Kalau ditinjau dari hubungan antar wilayah, tentu bervariasi. Karena bagaimana pun juga, setiap wilayah

${ }^{2}$ http://norickyujustice.blogspot.com/2011/04/st atus-hukum-anak-dari-hasil-perkawinan.html ${ }^{3}$ Ibid 
akan memberikan tanggapan berbeda dengan pemberlakukan UndangUndang Nomor 12 Tahun 2006 tentang Kewarganegaraan Negara Indonesia. Ini memang memerlukan pengkajian secara mendalam. Dalam konsep sosialisasi, terdapat beberapa komponen yang mengalami reaksi terhadap perubahan pemberlakuan Undang-Undang tersebut. Pertama, adalah masyarakat sendiri, di mana aturan yang terlalu ketat akan mempengaruhi sistem kependudukan di wilayah tersebut. Warganegara Indonesia yang sudah melakukan perkawinan campuran dengan Warga Negara Asing. Dengan terjadinya perubahan ini, maka secara pribadi mereka tentu akan kembali melakukan koordinasi dengan negara asalnya.

Dan ada kemungkinan, penerimaan mereka pun akan semakin kurang bersahabat. Langkah yang harus diambil, adalah lebih cepat melakukan koordinasi dengan negara sahabat serta negara yang kebanyakan warga negaranya telah membaur menjadi warga negara Indonesia atau masih belum masuk menjadi Warga Negara Indonesia. Ini merupakan suatu tantangan untuk melaksanakan misinya merubah aturan lama. Hal ini juga akan mengakibatkan semakin banyaknya warga negara Indonesia yang memegang kewarganegaraan ganda. Dan tidak tertutup kemungkinan mereka akan lebih mudah melakukan kejahatan dan melarikan diri ke negara milik salah satu pasangan.Selain itu proses penanganan keimigrasian pun akan semakin kurang efektif.

Karena semakin ketat aturannya, biasanya diikuti oleh birokrasi yang semakin panjang. Dan ini akan menyebabkan keresahan bagi mereka yang memiliki kewarganegaraan ganda. Ini sungguh memprihatinkan. Kedua, Berkaitan dengan status dan kedudukan hukum anak dari hasil perkawinan campuran, mengingat dengan diberlakukannya Undangundang Nomor 12 tahun 2006 tentang Kewarganegaraan Republik Indonesia tentu saja membawa konsekuensi- konsekuansi yang berbeda dengan Undang-Undang yang terdahulu, di mana seorang anak sudah terlanjur dilahirkan dari suatu perkawinan campuran. ${ }^{4}$ Dalam perundangundangan di Indonesia, perkawinan campuran didefinisikan dalam Pasal 57 Undang-Undang Nomor 1 Tahun 1974 tentang Perkawinan: "Yang dimaksud dengan perkawinan campuran dalam Undang-undang ini ialah, perkawinan antara dua orang yang di Indonesia tunduk pada hukum yang berlainan, karena perbedaan kewarganegaraan dan salah satu pihak berkewarganegaraan asing dan salah satu pihak berkewarganegaraan Indonesia."

Selama hampir setengah abad, pengaturan kewarganegaraan dalam perkawinan campuran antara Warga Negara Indonesia dengan Warga Negara Asing, mengacu pada UndangUndang Nomor 62 Tahun 1958 tentang Kewarganegaraan. Seiring berjalannya waktu, Undang-Undang ini dinilai tidak sanggup lagi mengakomodir kepentingan para pihak dalam perkawinan campuran, terutama perlindungan untuk istri dan anak. Barulah pada 11 Juli 2006, Dewan Perwakilan Rakyat mengesahkan Undang-Undang Kewarganegaraan yang baru. Lahirnya Undang-Undang ini disambut gembira oleh sekelompok kaum ibu yang menikah dengan Warga Negara Asing, walaupun pro dan kontra masih saja timbul, namun secara garis besar Undang-undang baru yang memperbolehkan dwi kewarganegaraan terbatas ini sudah memberikan perubahan baru dalam mengatasi persoalan-persoalan yang lahir dari perkawinan campuran.

Anak adalah subjek hukum yang belum cakap melakukan perbuatan hukum sendiri sehingga harus dibantu oleh orang tua atau walinya yang memiliki kecakapan. Pengaturan status hukum anak hasil perkawinan campuran dalam Undang-Undang Kewarganegaraan yang baru, memberi 
perubahan yang positif, terutama dalam hubungan anak dengan ibunya, karena Undang-Undang baru ini mengizinkan kewarganegaraan ganda terbatas untuk anak hasil perkawinan campuran. Penulis juga menganalisis sejumlah potensi masalah yang bisa timbul dari kewarganegaraan ganda pada anak. Seiring berkembangnya zaman dan sistem hukum.

\section{Undang-Undang}

Kewarganegaraan yang baru ini penerapannya semoga dapat terus dikritisi oleh para ahli hukum perdata internasional, terutama untuk mengantisipasi potensi masalah. Sehingga dalam penulisan judul ini saya memilih " Kepastian Hukum Terhadap Anak Hasil Perkawinan Campuran Menurut Undang-Undang Nomor 12 Tahun 2006 Tentang Kewarganegaraan Republik Indonesia".

\subsection{Perumusan Masalah}

Berdasarkan latar belakang masalah tersebut diatas penulis mengetengahkan dua permasalahan yaitu :

1. Bagaimana Status Anak hasil perkawinan campuran menurut Undang-undang Nomor 12 tahun 2006 tentang kewarganegaraan Republik Indonesia?

2. Bagaimana Kepastian hukum terhadap harta benda pewaris ?

\subsection{Tujuan Penelitian}

Dalam penelitian ini ada dua tujuan yang ingin diketahui antara :

1. Untuk mengetahui status anak hasil perkawinan campuran (beda kewarganegaraan) yang sesuai dengan ketentuan berdasarkan undang-undang nomor 12 tahun 2006 tentang kewarganegaraan Republik Indonesia.

2. Untuk mengetahui Kepastian hukum terhadap harta warisan anak dengan ketentuan undangundang nomor 12 tahun 2006 tentang kewarganegaraan republik Indonesia.

\subsection{Manfaat Penelitian}

Di dalam penelitian sangat diharapkan adanya manfaat dan kegunaan karena nilai suatu penelitian ditentukan oleh besarnya manfaat yang dapat diambil dari penelitian tersebut. Adapun manfaat yang diharapkan penulis dari penelitian ini antara lain :

1. Manfaat Teoritis

a. Hasil penelitian ini diharapkan dapat memberikan sumbangan pemikiran bagi pengembangan ilmu hukum khususnya mengenai Kewarganegaraan Republik Indonesia.

b. Hasil penelitian ini dapat di pakai sebagai acuan bagi penelitian penelitian selanjutnya yang sejenis.

c. Diharapkan dengan adanya penelitian ini dapat ditemukan metode yang efektif guna mencegah bahkan mengatasi maraknya perkawinan campuran yang tidak sesuai dengan undang-undang yang berlaku di kemudian hari.

2. Manfaat Praktis

a. Hasil penelitian ini dapat meningkatkan dan mengembangkan daya pikir dan analisis penulis tentang masalah-masalah hukum, sekaligus untuk mengukur sejauh mana kemampuan penulis dalam menerapkan ilmu yang diperoleh selama kuliah di Fakultas Hukum Universitas Islam Lamongan.

b. Diharapkan dapat membantu dan member masukan serta tambahan pengetahuan bagi pihak yang terkait dengan masalah yang diteliti khususnya tentang perkawinan campuran.

c. Dapat memberikan sumbangan pemikiran bagi penegak hukum agar dipakai sebagai bahan pertimbangan dan dasar pengambilan keputusan ataupun kebijakannya dalam 
menangani perkawinan campuran.

d. Hasil penelitian ini diharapkan mampu menjawab permaslahan yang timbul diranah hukum tentang perkawinan campuran beserta pengaturan hukumnya.

\section{METODE PENELITIAN}

Tipe Penelitian hukum yang di lakukan adalah penelitian Yuridis normatife (hukum normatif). Metode Penelitian Hukum normatif adalah suatu prosedur penelitian ilmiah untuk menemukan kebenaran berdasarkan logika keilmuan hukum dari sisi normatifnya. ${ }^{5}$ Oleh karena tipe penelitian yang di gunakan adalah tipe penelitian yuridis normatif, maka pendekatan yang digunakan adalah pendekatan perundang-undangan (statute approach) dan pendekatan konsep (conseptual). Pendekatan konsep ini di gunakan dalam rangka untuk melihat konsep - konsep mengenai Kepastian Hukum Terhadap Anak Hasil dari Perkawinan Campuran Menurut Undang-undang Nomor 12 Tahun 2006. Jika demikian, pendekatan peraturan perundangundangan adalah pendekatan dengan menggunakan legislasi dan regulasi. ${ }^{6}$

Bahan hukum yang di pergunakan dalam penelitian ini adalah sebagai berikut: Bahan hukum primer yakni bahan hukum terdiri dari perundang-undangan, catatan resmi, atau risalah dalam pembuatan perundang-undangan dan putusan hakim. Bahan sekunder adalah bahan hukum yang diperoleh dari buku teks,jurnal-jurnal asing, pendapat para sarjana dan kasus-kasus hukum,serta symposium yang dilakukan para pakar. Bahan Hukum tersier adalah bahan hukum seperti kamus hukum,

${ }^{5}$ Jhonny ibrahim, Teori \& Metode

Penelitian Hukum Normatif, Banyumedia

Publishing, Malang 2006.h .57.

${ }^{6}$ Peter Mahmud Marzuki, Penelitian

Hukum, Kencana Prenada Media Group,

Jakarta, 2010, h, 96. ensiklopedia dan lain-lain. Maka dalam pengumpulan bahan hukum penulis mengunakan studi dokumen atau bahan pustaka dalam penulisan skripsi ini.

\section{HASIL DAN PEMBAHASAN}

Pemberlakuan Undang-Undang Nomor 12 Tahun 2006 Tentang Kewarganegaraan Repubik Indonesia, memunculkan sederet aturan dan petunjuk pelaksanaan itu rupanya belum membuat urusan kawin campuran selesai seratus persen. Apabila perkawinan campuran yang berbeda kewarganegaraan, masalah kedudukan anak atau status anak ini memang dapat menimbulkan permasalahan. Karena Indonesia menganut asas keturunan (asas ius sanguinis) yaitu kewarganegaraan seseorang ditentukan oleh keturunan dari pada orang yang bersangkutan (si suami). Selanjutnya apabila perkawinan tidak berjalan mulus dan terjadi kekerasan yang akhirnya terjadi perceraian maka akan timbul permasalahan si anak menjadi warganegara yang mana (ikut Ayah atau ikut Ibu). Jumlah peristiwa perkawinan campuran yang terjadi di Indonesia cenderung meningkat dan hal tersebut mengakibatkan permasalahan yang berkaitan dengan penentuan status kewarganegaraan anak dari perkawinan tersebut.

Konsekuensi hukum status anak hasil perkawinan kewarganegaraan Indonesia dan asing (Ius Sanguinis). Status anak dari perkawinan campuran yang putus karena cerai dan di bawah pengasuhan Ibunya. Perkawinan antara seorang pria Warga Negara Asing dengan Warga Negara Indonesia dan perkawinan tersebut putus karena perceraian padahal anaknya masih dibawah umur, maka anak dari perkawinan tersebut diputus oleh Pengadilan dibawah asuhan ibunya yang Warga Negara Indonesia, padahal status anak tersebut adalah Warga Negara Asing. Oleh karena itu untuk melindungi anak tersebut, sebaiknya si ibu mengajukan permohonan kewarganegaraan Indonesia kepada 
pengadilan. Atau si anak dapat memilih sendiri kewarganegaraannya setelah berumur 18 tahun).

Anak yang lahir sebagaimana dimaksud dalam Undang-undang Nomor 12 Tahun 2006 Tentang Kewarganegaraan Republik Indonesia Pasal 4 huruf c, huruf d, huruf h, huruf I dan anak yang diakui atau diangkat secara sah sebagaimana dimaksud dalam Pasal 5 yakni :"sebelum undangundang ini diundangkan dan belum berusia 18 (delapan belas) tahun atau belum kawin memperoleh Kewarganegaraan Republik Indonesia berdasarkan undang-undang ini dengan mendaftarkan diri kepada Menteri melalui Pejabat atau Perwakilan Republik Indonesia paling lambat 4 (empat) tahun setelah undang-undang ini diundangkan".

Pengesahan Undang-undang Nomor 12 Tahun 2006 tentang Kewarganegaraa Republik Indonesia, merupakan momentum bersejarah bagi seluruh masyarakat Indonesia. Kelahiran undang-undang ini memiliki nilai historis karena produk hukum yang digantikan, yakni Undang-undang Nomor 62 Tahun 1958 merupakan peninggalan rezim orde lama yang dilestarikan orde baru. Konfigurasi politik era orde lama dan orde baru relatif otoritarian, cenderung melahirkan produk hukum konservatif. Sedangkan di era reformasi, karakter politik cenderung demokratis melahirkan aturan-aturan legal yang responsif. Perubahan konfigurasi politik inilah yang mengantarkan undang-undang kewarganegaraan dari yang berwatak konservatif menjadi responsif.

Perwujudan Undang-Undang kewarganegaraan Republik Indonesia yang lama tercermin pada aturan legal yang bersifat diskriminatif, kurang menjamin pemenuhan hak asasi dan persamaan antarwarga negara serta kurang memberikan perlindungan terhadap perempuan dan anak-anak. Berdasarkan Undang-undang Nomor 62 Tahun 1958 tentang Kewarganegaraa dalam Pasal 8 Ayat (1):
"Bahwa seorang wanita WNI yang melakukan kawin campur, maka akan kehilangan kewarganegaraan-nya. Begitupun anak yang dilahirkan dari perkawinan antara wanita Warga Negara Indonesia dengan pria Warga Negara Asing, otomatis mengikuti kewarganegaraan ayahnya".

Sedangkan perwujudan demokratisasi Negara dalam undangundang Kewarganegaraan yang baru tercermin dari produk hukumnya yang responsif, yakni dalam bentuk persamaan perlakuan dan kedudukan warga negara dihadapan hukum serta adanya kesetaraan dan keadilan gender. Menurut Undang-undang Nomor 12 Tahun 2006 tentang Kewarganegaraan Republik Indonesia dalam Pasal 2 disebutkan :

"Bahwa warga negara asli Indonesia adalah orang Indonesia yang menjadi warga negara Indonesia sejak kelahirannya dan tidak pernah menerima kewarganegaraan lain atas kehendak sendiri”.

Undang-undang Nomor 12 Tahun 2006 Tentang Kewarganegaraan Republik Indonesia ini menyiratkan penolakan konsep diskriminasi dalam perolehan kewarganegaraan atas dasar ras, etnik, dan gender, maupun diskriminasi yang didasarkan pada status perkawinan. Dalam pasal lain juga disebutkan, Warga Negara Indonesia yang menikah dengan pria Warga Negara Asing tidak lagi dianggap otomatis mengikuti kewarganegaraan suaminya, melainkan diberi tenggang waktu tiga tahun untuk menentukan pilihan, apakah akan tetap menjadi Warga Negara Indonesia atau melepaskannya. Selain itu, apabila istri memutuskan tetap menjadi Warga Negara Indonesia atau selama masa tenggang waktu tiga tahun itu, ia bisa menjadi sponsor izin tinggal suaminya di Indonesia. Peraturan 
kewarganegaraan dalam hukum berbagai negara memang beraneka ragam, tiadanya keseragaman ini paling jelas kelihatan pada perbedaanperbedaan dalam cara mendapatakan kewarganegaraan. ${ }^{7}$

Bagian yang paling penting dari undang-undang baru ini adalah dianutnya asas campuran Ius Sanguinis - Ius Solli dan mengakui kewarganegaraan ganda pada anak-anak dari pasangan kawin campur dan anakanak yang lahir dan tinggal di luar negeri hingga usia 18 tahun. Artinya sampai anak berusia 18 tahun, diizinkan memiliki dua kewarganegaraan. Setelah mencapai usia tersebut ditambah tenggang waktu tiga tahun barulah si anak diwajibkan memilih salah satunya. Ketentuan inilah yang menghindari terjadinya stateless. Mencermati isi materi undang-undang kewarganegaraan yang baru tampaknya lebih merupakan bentuk akomodasi sebuah masyarakat yang telah in touch dengan pergaulan internasional. Undang-undang ini tampaknya secara filosofis ingin mengatakan bahwa akulturasi budaya melalui media kewarganegaraan menjadi sesuatu yang tidak terhindarkan.

Di sini, hukum sebagai social engineering atau perekaya sosial berfungsi. Hanya saja penetrasi tata nilai yang ada didalamnya, sebagai akibat percampuran perkawinan, misalnya, berada di luar konteks undang-undang tersebut. Negara, yang telah berhasil menghasilkan undang-undang progresif ini, harus juga memberikan pemahaman yang komprehensif kepada sekelompok masyarakat yang ketat menjaga nilainilai adat dan agama, yang menolak tradisi kawin campur karena kental bermuatan sara. Sehingga produk hukum yang sangat dibanggakan ini menjadi lebih acceptable. Perkawinan campuran telah merambah seluruh pelosok tanah air dan lapisan masyarakat. Globalisasi informasi,

7 J.G. Starke, Pengantar Hukum Internasional, Edisi Kesembilan, Jakarta, Aksara Persada, 1989, h. 24. ekonomi, pendidikan, dan transportasi telah menggugurkan stigma bahwa kawin campur adalah perkawinan antara ekspatriat kaya dan orang Indonesia. Menurut hasil survei online yang dilakukan.

Indo-MC tahun 2002, dari 574 responden yang terjaring, 95,19\% adalah perempuan warga Warga Negara Indonesia yang menikah dengan pria Warga Negara Asing. Angka terbesar adalah perkenalan melalui internet, kemudian bekas teman kerja/bisnis, berkenalan saat berlibur, bekas teman sekolah dan sahabat pena. Perkawinan campur terjadi pada tenaga kerja Indonesia dengan tenaga kerja dari negara lain. Di lain pihak, Kantor Catatan Sipil DKI Jakarta mencatat 878 perkawinan selama tahun 2002 sampai tahun 2004 dan 94,4 persennya adalah perempuan Warga Negara Indonesia yang menikah dengan pria Warga Negara Asing (829 pernikahan). Angka tersebut belum termasuk pernikahan di Kantor Urusan Agama yang tidak didaftarkan di Kantor Catatan Sipil dan di seluruh Indonesia. ${ }^{8}$ Dalam Undangundang Nomor 1 Tahun 1974 tentang Perkawinan, dijelaskan bahwa perkawinan campuran adalah perkawinan antara dua orang yang di Indonesia tunduk pada hukum yang berlainan, karena perbedaan kewarganegaraan dan salah satu pihak berkewarganegaraan Indonesia.

Apabila perkawinan campuran tersebut dilangsungkan di Indonesia, maka perkawinan tersebut harus dilakukan menurut Undang-undang Perkawinan ini, sedangkan bila perkawinan dilangsungkan diluar Indonesia, maka perkawinan tersebut dianggap sah bila dilakukan menurut hukum yang berlaku di negara di mana perkawinan itu dilangsungkan, dan bagi warga negara Indonesia tidak melanggar Undang-undang ini. Selanjutnya, dalam waktu 1 (satu) tahun setelah suami istri itu kembali di wilayah Indonesia, surat bukti perkawinan mereka harus

\footnotetext{
${ }^{8}$ http://norickyujustice.blogspot.com/Op.cit
} 
didaftarkan di Kantor Pecatatan Perkawinan tempat tinggal mereka. Pencatatan ini penting dilakukan agar perkawinan campuran tersebut dianggap sah berdasarkan Undang-undang ini. Sehingga apabila terjadi sesuatu terhadap perkawinan ini, misalnya saja perceraian, maka mengenai perceraian tersebut beserta akibat-akibatnya akan diatur berdasarkan Undang-undang yang berlaku di Indonesia.

Mengenai anak yang dilahirkan dari perkawinan campuran, dahulu diatur berdasarkan UndangUndang Nomor 62 tahun 1958 (sekarang sudah digantikan dengan Undang-undang Nomor 12 tahun 2006). Dahulu (berdasarkan Undang-undang Nomor 62 tahun 1958), anak yang dilahirkan dari perkawinan campur antara laki-laki warga negara asing dengan perempuan berwarga negara Indonesia, maka anak yang dilahirkan akan mengikuti hukum ayahnya. Demikian pula bila anak yang dilahirkan dari perkawinan campuran antara laki-laki warga negara Indonesia dengan wanita warga negara asing, maka anak yang dilahirkan akan mengikuti hukum ayahnya yang warga negara Indonesia.

Sedangkan berdasarkan Undangundang Nomor 12 tahun 2006 tentang kewarganegaraan Republik Indonesia, maka seorang anak yang dilahirkan berdasarkan perkawinan campuran dengan tidak memandang apakah ayah atau ibunya yang warga negara asing dengan demikian anak tersebut dapat memiliki kewarganegaraan ganda. Namun pada saat berusia 18 tahun atau sudah kawin, anak tersebut harus menyatakan memilih salah satu kewarganegaraannya. Dalam suatu perkawinan campuran, kembali harus dilihat hukum mana yang mereka sepakati untuk digunakan dengan melihat bagaimana perkawinan itu dilakukan.

Karena berhubungan dengan orang asing yang mempunyai sistem hukum yang berbeda, sebaiknya dalam suatu perkawinan campuran sudah seharusnya dilakukan melalui prosedur hukum yang benar sesuai dengan peraturan perundang-undangan yang berlaku dan sedapat mungkin disertai dengan perjanjian perkawinan yang menyangkut tentang status harta benda dalam perkawinannya nanti. Dengan demikian, kepastian hukum dalam perkawinan yang dilaksanakan dapat lebih terjamin bagi semua pihak. Sesuai dengan Undang-Undang Nomor 1 tahun 1974 tentang Perkawinan , dalam perkawinan tanpa perjanjian kawin semua harta benda yang diperoleh dalam perkawinan menjadi harta bersama kecuali ditentukan lain. Dalam perkawinan campuran ada baiknya juga membuat perjanjian kawin yang memberi perlindungan pada kedua pihak agar tidak ada orientasi negatif terhadap keinginan terhadap harta benda.

Perkawinan campuran Warga Negara Asing dan Warga Negara Indonesia yang membuat perjanjian pranikah biasanya mengatur tentang penegasan kepemilikan harta benda walaupun diatas namakan salah satu tetap merupakan harta bersama ( selalu dengan persetujuan walaupun atas nama sendiri), yang sebenarnya tidak perlu diperjanjikan namun hukum Indonesia sendiri lemah dalam pelaksanaan yang menganggap bila tanah hak atas nama sendiri boleh dijual tanpa persetujuan suami/istri dan/atau anak (dewasa atau belum dewasa) dan badan pertanahan juga tidak mengurusi keabsahan ijin yang dianggap sudah diteliti oleh PPAT. Perjanjian pranikah itu juga lebih melindungi kepentingan Warga Negara Asing yang umumnya sebagai pemilik uang.

Secara umum pernikahan yang dilakukan di Indonesia akan mengikuti hukum waris Indonesia atau bila pernikahan dilakukan di luar negeri dan dicatatkan di Indonesia serta tinggal di Indonesia, dan keduanya atau salah satu adalah Warga Negara Indonesia. Hukum waris secara umum di banyak negara mengakui adanya harta bersama dalam perkawinan dan wasiat, serta cara penguasaannya oleh Warga Negara Asing diatur sesuai kepentingan 
perlindungan hukum negara masingmasing. Apabila pihak suami warga negara Indonesia, maka ketentuan hukum material berkaitan dengan harta kekayaan diatur berdasarkan hukum suami, yaitu Undang-undang Nomor 1 Tahun 1974 Tentang Perkawinan.

Namun harta benda perkawinan campuran ini apabila tidak dilakukan perjanjian perkawinan yang menyangkut harta perkawinan maka berkenaan dengan harta perkawinan ini akan tunduk pada Pasal 35, dimana ditentukan, bahwa :

(1) Harta benda yang diperoleh selama perkawinan menjadi harta bersama;

(2) Harta bawaan dari masingmasing suami dan isteri dan harta benda yang diperoleh masing-masing sebagai hadiah atau warisan, adalah dibawah penguasaan masin-masing sepanjang para pihak tidak menentukan lain.

Selanjutnya mengenai harta bersama ini dapat dikelola bersamasama suami dan isteri, namun dalam setiap perbuatan hukum yang menyangkut harta bersama harus ada persetujuan kedua belah pihak (Pasal 36 ayat (1)). Sedangkan dalam hal harta bawaan masing-masing suami dan isteri mempunyai hak sepenuhnya untuk melakukan perbuatan hukum mengenai harta bendanya Pasal 36 ayat (2)).

Apabila terjadi perceraian, maka harta bersama diatur menurut hukumnya masing-masing (Pasal 37), yang dimaksud hukum masing-masing pihak di dalam undang-undang Perkawinan ini adalah hukum agama, hukum adat atau hukum lainnya. Untuk Perkawinan Campuran akan menjadi masalah Hukum Perdata internasional, karena akan terpaut 2 (dua) sistem hukum perkawinan yang yang berbeda, yang dalam penyelesaiannya dapat digunakan ketentuan Pasal 2 dan Pasal 6 ayat (1) GHR (Regeling of de gemengde huwelijken) S. 1898 yaitu diberlakukan hukum pihak suami.

Masalah harta perkawinan campuran ini apabila pihak suami warganegara Indonesia, maka tidak ada permasalahan, karena diatur berdasarkan hukum suami yaitu Undang-undang Nomor 1 Tahun 1974 Tentang Perkawinan. Sedangkan apabila isteri yang berkebangsaan Indonesia dan suami berkebangsaan asing maka dapat menganut ketentuan Pasal 2 dan Pasal 6 ayat (1) GHR (Regeling of de gemengde huwelijken), yaitu diberlakukan hukum pihak suami. Namun karena GHR (Regeling of de gemengde huwelijken) tersebut adalah pengaturan produk zaman Belanda, sebaiknya masalah ini diatur dalam Hukum Nasional, yang disesuaikan dengan perkembangan zaman. Konsekuensi atau akibat hukum perceraian terhadap harta bersama diatur dalam Pasal 37 Undang-Undang Nomor 1 Tahun 1974 Tentang Perkawinan yang menyatakan:

"Bila perkawinan putus karena perceraian, harta bersama diatur menurut hukumnya masingmasing." Lebih jauh dalam Penjelasan Pasal 37 UndangUndang Nomor 1974 Tentang Perkawinan disebutkan bahwa : "Yang dimaksud dengan "hukumnya" masing-masing ialah hukum agama, hukum adat dan hukum-hukum lainnya."

H. Hilman Hadikusuma menjelaskan dalam buku Hukum Perkawinan Indonesia Menurut: Perundangan Hukum Adat Hukum Agama, akibat hukum yang menyangkut harta bersama berdasarkan 
Pasal 37 Undang-Undang Nomor 1 Tahun 1974 Tentang Perkawinan ini diserahkan kepada para pihak yang bercerai tentang hukum mana dan hukum apa yang akan berlaku, dan jika tidak ada kesepakatan antara mantan suami-istri, hakim dapat mempertimbangkan menurut rasa keadilan yang sewajarnya. ${ }^{9}$ Jadi, akibat suatu perceraian terhadap harta bersama bagi setiap orang dapat berbeda-beda, tergantung dari hukum apa dan mana yang akan digunakan para pihak untuk mengatur harta bersama. Penjelasan lebih jauh mengenai frasa "hukumnya masingmasing" dalam Pasal 37 UndangUndang Nomor 1 Tahun 1974 Tentang Perkawinan ini, karena jumlahnya dan ragamnya banyak sekali. Tapi sebagai contoh dapat di jelaskan beberapa hal sebagai berikut: ${ }^{10}$

a. Untuk yang beragama Islam, ada ketentuan mengenai pembagian harta bersama dalam Kompilasi Hukum Islam ("KHI”). Pasal 97 KHI mengatur :

"janda atau duda cerai hidup masing-masing berhak seperdua dari harta bersama sepanjang tidak ditentukan lain dalam perjanjian perkawinan."

b. Bagi umat Katolik pada dasarnya tidak ada perceraian dalam agama Katolik, karena agama Katolik menolak adanya perceraian. Namun dalam praktiknya, pasangan Katolik tetap dapat bercerai secara perdata, walaupun secara Katolik perceraian tersebut dianggap tidak sah. Lebih jauh simak artikel Perceraian Agama Katolik dan Perceraian Agama Katolik (2). Dalam hal yang demikian, perceraian dan

${ }^{9} \mathrm{http}: / / \mathrm{www} \cdot h \mathrm{hukumonline.com} / \mathrm{klin}$ ik/detail/lt4f3b41b9d92da/dampakperceraian terhadap-harta-bersama${ }^{10} \mathrm{Ibid}$. pembagian harta bersama berpedoman pada ketentuanketentuan Kitab Undang-Undang Hukum Perdata ("KUHPer"). Berdasarkan Pasal 126 KUHPer, harta bersama bubar demi hukum salah satunya karena perceraian. Lalu, setelah bubarnya harta bersama, kekayaan bersama mereka dibagi dua antara suami dan isteri, atau antara para ahli waris mereka, tanpa mempersoalkan dan pihak mana asal barang-barang itu (Lihat Pasal 128 KUHPer). Jadi, berdasarkan Pasal 37 UndangUndang Nomor 1 Tahun 1974 Tentang Perkawinan jo Pasal 126 dan 128 Kitab Undang-undang Hukum Perdata, perceraian mengakibatkan bubarnya harta bersama sehingga harta bersama tersebut harus dibagi diantara pasangan suami-istri.

c. Selain itu, akibat perceraian terhadap harta bersama juga dapat ditentukan oleh hukum adat yang digunakan para pihak, apabila para pihak menggunakan hukum adat untuk mengatur akibat perceraian. Sehingga, segala sesuatu mengenai harta bersama diatur berdasarkan hukum adat yang berlaku masing-masing, dan tidak ada kesamaan antara masyarakat adat yang satu dan yang lainnya. Misalnya pada masyarakat matrilineal seperti masyarakat Minang, umumnya berlaku hukum adat yang menentukan akibat hukum perceraian terhadap harta bersama yaitu harus dibagi antara suami dan istri

Jika salah satu pihak dalam perkawinan adalah warga negara asing, perkawinan tersebut merupakan suatu perkawinan campuran. Perkawinan campuran adalah perkawinan antara dua orang yang di Indonesia tunduk pada hukum yang berlainan, karena 
perbedaan kewarganegaraan dan salah satu pihak berkewarganegaraan Indonesia (Pasal 57 Undang-Undang Nomor 1 Tahun 1974 Tentang Perkawinan). Dalam hal ini harus jelas perkawinan dilangsungkan dimana. Karena, suatu perkawinan adalah sah berdasarkan hukum dimana perkawinan tersebut dilangsungkan. Jika perkawinan itu kemudian tidak dicatatkan di Indonesia, maka perkawinan tersebut tetap tunduk pada hukum dimana perkawinan dilangsungkan.

Yakni dalam hal terjadi perceraian, harus dilakukan dimana perkawinan dilangsungkan Pasal 56 ayat Undang-undang Nomor 1 Tahun 1974 Tentang Perkawinan. Namun, jika perkawinan dilangsungkan di Indonesia dan tunduk pada hukum Indonesia, yang berlaku adalah ketentuan Pasal 37 Undang-undang Nomor 1 Tahun 1974 Tentang Perkawinan sebagaimana telah dijelaskan yakni, untuk menentukan hukum mana dan hukum apa yang berlaku terkait dengan harta bersama diserahkan pada kesepakatan para pihak yang bercerai.

Jika tidak ada kesepakatan antara mantan suami-istri, hakim dapat mempertimbangkan menurut rasa keadilan yang sewajarnya. Jadi, bila tidak ada kesepakatan para pihak mengenai akibat perceraian terhadap harta bersama, hakimlah yang akan menentukan hukum apa dan mana yang akan diterapkan. Dan apabila ada faktor lain dalam perceraian yakni sang ayah atau ibu meninggal dunia maka harta warisan akan diatur setelah anak berumur 18 tahun karena pada saat itu juga anak akan memilih kewarganegaraannya.

\section{KESIMPULAN}

Dalam Undang-undang Nomor 1 Tahun 1974 tentang Perkawinan, dijelaskan bahwa perkawinan campuran adalah perkawinan antara dua orang yang di Indonesia tunduk pada hukum yang berlainan. Mengenai anak yang dilahirkan dari perkawinan campuran, berdasarkan Undang-undang Nomor 12 tahun 2006 tentang kewarganegaraan Republik Indonesia, maka seorang anak yang dilahirkan berdasarkan perkawinan campuran dengan tidak memandang apakah ayah atau ibunya yang warga negara asing dengan demikian anak tersebut dapat memiliki kewarganegaraan ganda. Namun pada saat berusia 18 tahun atau sudah kawin, anak tersebut harus menyatakan memilih salah satu kewarganegaraannya.

Sesuai dengan Undang-Undang Nomor 1 tahun 1974 tentang Perkawinan, dalam perkawinan tanpa perjanjian kawin semua harta benda yang diperoleh dalam perkawinan menjadi harta bersama kecuali ditentukan lain. Hukum waris secara umum di banyak negara mengakui adanya harta bersama dalam perkawinan dan wasiat, serta cara penguasaannya oleh Warga Negara Asing diatur sesuai kepentingan perlindungan hukum negara masing-masing. Ketentuan yang mengatur untuk harta benda pewaris disesuaikan dengan adanya suatu perkawinan yang sah, dan pengaturan atau system pembagian warisan tersebut juga disesuaikan dengan hukum masingmasing baik dari pihak istri yang berkewarganegaraan indonesia dan suami yang berkewarganegaraan asing.

\section{DAFTAR PUSTAKA}

C.S.T. Kansil, Pengantar Ilmu Hukum Indonesia, Rineka Cipta, Jakarta, Tahun 2011.

J.G. Starke, Pengantar Hukum Internasional, $\quad$ Edisi Kesembilan, Aksara Persada, Jakarta, Tahun 1989.

Jhony ibrahim, Teori \& Metode Penelitian Hukum Normatif, Banyumedia Publishing, Malang, Tahun 2006.

Peter Mahmud Marzuki, Penelitian Hukum, Kencana Prenadia Group, Jakarta, Tahun 2010 
Subekti, Pokok-Pokok Hukum

Perdata, (cetakan ke-31),

Intermasa, Jakarta, Tahun 2003.

Titik Triwulan Tutik, Konstitusi Hukum Tata Negara Indonesia Pasca Amandemen UUD 1945, Kencana, Jakarta, Tahun 2010.

Peraturan Perundang-Undangan :

Undang-undang Dasar Negara Republik Indonesia Tahun 1945

Kitab Undang-undang Hukum Perdata (KUHPerdata)

Undang-undang Nomor 1 Tahun 1974 Tentang Perkawinan

Undang-undang Nomor 12 Tahun 2006 Tentang
Kewarganegaraan Republik

Indonesia

Undang-undang Nomor 23 Tahun 2003 Tentang Perlindungan Anak

\section{Internet :}

http://norickyujustice.blogspot.com/20 11/04/status-hukum-anak-darihasil-perkawinan.html

http://fairyvact.blogspot.com/2010/02/ harta-benda-dalamperkawinan.html

http://www.hukumonline.com/klinik/d etail/lt4f3b41b9d92da/dampak -perceraianterhadap-hartabersama- 